\title{
Virocidal activity of Egyptian scorpion venoms against hepatitis $C$ virus
}

\author{
Alaa MH El-Bitar ${ }^{1,2}$, Moustafa MH Sarhan ${ }^{1}$, Chie Aoki ${ }^{2}$, Yusuke Takahara ${ }^{2}$, Mari Komoto $^{2}$, Lin Deng², \\ Mohsen A Moustafa ${ }^{1}$ and Hak Hotta ${ }^{2 *}$
}

\begin{abstract}
Background: Hepatitis C virus (HCV) is a major global health problem, causing chronic hepatitis, liver cirrhosis and hepatocellular carcinoma. Development of well-tolerated regimens with high cure rates and fewer side effects is still much needed. Recently, natural antimicrobial peptides (AMPs) are attracting more attention as biological compounds and can be a good template to develop therapeutic agents, including antiviral agents against a variety of viruses. Various AMPs have been characterized from the venom of different venomous animals including scorpions.

Methods: The possible antiviral activities of crude venoms obtained from five Egyptian scorpion species (Leiurus quinquestriatus, Androctonus amoreuxi, A. australis, A. bicolor and Scorpio maurus palmatus) were evaluated by a cell culture method using Huh7.5 cells and the J6/JFH1-P47 strain of HCV. Time-of-addition experiments and inactivation of enzymatic activities of the venoms were carried out to determine the characteristics of the anti-HCV activities.

Results: S. maurus palmatus and A. australis venoms showed anti-HCV activities, with $50 \%$ inhibitory concentrations $\left({ }^{(} C_{50}\right)$ being $6.3 \pm 1.6$ and $88.3 \pm 5.8 \mu \mathrm{g} / \mathrm{ml}$, respectively. S. maurus palmatus venom $(30 \mu \mathrm{g} / \mathrm{ml})$ impaired HCV infectivity in culture medium, but not inside the cells, through virocidal effect. The anti-HCV activity of this venom was not inhibited by a metalloprotease inhibitor or heating at $60^{\circ} \mathrm{C}$. The antiviral activity was directed preferentially against HCV.

Conclusions: S. maurus palmatus venom is considered as a good natural source for characterization and development of novel anti-HCV agents targeting the entry step. To our knowledge, this is the first report describing antiviral activities of Egyptian scorpion venoms against HCV, and may open a new approach towards discovering antiviral compounds derived from scorpion venoms.
\end{abstract}

Keywords: Hepatitis C virus, HCV, Antiviral activity, Scorpion venom, Scorpio maurus palmatus, Egypt

\section{Introduction}

Hepatitis $\mathrm{C}$ virus (HCV) infection is a major global health problem, with estimated more than 170 million infected individuals worldwide. HCV is an enveloped, positivestrand RNA virus that belongs to the Hepacivirus genus of the Flaviviridae family [1-3]. HCV infection is the serious cause of chronic hepatitis, hepatic steatosis, liver cirrhosis and eventually hepatocellular carcinoma after a few decades. There is no anti-HCV vaccine available and therapeutic options are still limited. The current standard therapy, which is based on pegylated interferon and ribavirin, is only partially effective, resulting in a sustained

\footnotetext{
* Correspondence: hotta@kobe-u.ac.jp

${ }^{2}$ Division of Microbiology, Kobe University Graduate School of Medicine,

7-5-1 Kusunoki-cho, Chuo-ku, Kobe 650-0017, Hyogo, Japan

Full list of author information is available at the end of the article
}

virological response (SVR) in about $50 \%$ of patients and has considerable side effects [1,3]. Recently, HCV NS3 protease inhibitors and NS5A inhibitors have been approved for clinical use and SVR rates have improved to reach $70 \%$ or higher [4-8]. However, these therapies are quite expensive and will probably not be accessible for all patients worldwide. For this reason, the development of new classes of safe and inexpensive antiviral compounds with improved efficacy is still needed for treatment of HCV infections.

Recently, natural antimicrobial peptides (AMPs) are attracting more attention as therapeutic agents against a variety of microbes including antibiotics-resistant strains $[9,10]$. Most AMPs share certain common features such as being small peptides of 10 to 50 amino acid residues, containing positive charge of 2 to 9 residues and an 
amphipathic structure [11-13]. These peptides exhibit a broad spectrum of antiviral and antibacterial activities, with direct or indirect microbicidal activities [12]. AMPs have been isolated from venomous animals including scorpions. Scorpion venoms consist of a cocktail of biologically active peptides that represent a tremendous potential for use in drug design and development [14-17]. Most scorpion venom peptides are composed of 20 to 75 amino acid residues while certain proteins, enzymes, consist of 120 to 370 residues [17]. Scorpion venom peptides show a vast array of biochemical activities and pharmacological functions. They can be classified into two classes, i.e., disulfide-bridged and non-disulfide-bridged peptides [18-20]. AMPs found in scorpion venoms are paid more and more attention due to their unique biological activities that can potentially be used as broadspectrum antiviral agents [9,21-28]. Scorpion venom AMPs are positively charged amphipathic peptides and can be divided into three structural categories: (i) cysteine containing peptides with disulfide bridges; (ii) peptides with an amphipathic $\alpha$-helix but lacking cysteine residues and (iii) peptides rich in certain amino acids such as proline and glycine [29].

The list of Egyptian scorpions currently includes 24 species classified under 13 genera within four different families, Buthidae, Diplocentridae, Euscorpiidae and Scorpionidae [30]. In the present study, we screened crude venoms obtained from five Egyptian scorpion species, Leiurus quinquestriatus, Androctonus amoreuxi, A. australis, A. bicolor and Scorpio maurus palmatus, for possible anti-HCV activities using an HCV cell culture system. We report here that crude venoms of $S$. maurus palmatus, and $A$. australis to a lesser extent, possess antiviral activities against HCV. To our knowledge, this is the first report describing anti-HCV activities of Egyptian scorpion venoms.

\section{Results}

Screening of anti-HCV activities of scorpion venoms

Anti-HCV activities of crude venoms of five Egyptian scorpion species were tested. As shown in Table 1, A. australis and S. maurus palmatus showed anti-HCV

Table 1 Antiviral activity (IC $\mathrm{C}_{50}$ ) against HCV, cytotoxicity $\left(\mathrm{CC}_{50}\right)$ and selectivity index (SI) of crude venoms of five Egyptian scorpion species tested in this study

\begin{tabular}{llll}
\hline Species & $\mathbf{I C}_{\mathbf{5 0}}\left(\boldsymbol{\mu \mathbf { g } / \mathbf { m l } ) ^ { \mathbf { a } }}\right.$ & $\mathbf{C C}_{\mathbf{5 0}}\left(\boldsymbol{\mu \mathbf { g } / \mathbf { m l } ) ^ { \mathbf { a } }}\right.$ & $\mathbf{S I}$ \\
\hline Leiurus quinquestriatus & $>100$ & $>100$ & na \\
Androctonus amoreuxi & $>100$ & $>100$ & na \\
Androctonus australis & $88.3 \pm 5.8$ & $>300$ & $>3.4$ \\
Androctonus bicolor & $>100$ & $>100$ & na \\
Scorpio maurus palmatus & $6.3 \pm 1.6$ & $>100$ & $>15.8$ \\
\hline
\end{tabular}

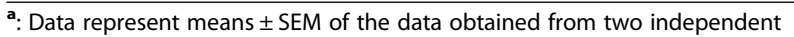
experiments using the J6/JFH1-P47 strain of HCV. na: Not applicable. activities, with $\mathrm{IC}_{50}$ being $88.3 \pm 5.8$ and $6.3 \pm 1.6 \mu \mathrm{g} / \mathrm{ml}$, respectively. Their $\mathrm{CC}_{50}$ were $>300$ and $>100 \mu \mathrm{g} / \mathrm{ml}$, respectively, with their selectivity indexes (SI; $\mathrm{CC}_{50} / \mathrm{IC}_{50}$ ) being $>3.4$ and $>15.8$, respectively. Crude venoms of the other three scorpion species did not exhibit significant anti-HCV activities at the concentration of $100 \mu \mathrm{g} / \mathrm{ml}$. Dose-dependent anti-HCV activity of $S$. maurus palmatus is shown in Figure 1.

\section{HCV inhibitory mechanisms of the S. maurus palmatus venom}

To further explore the mode of action of the S. maurus palmatus venom, time-of-addition experiments were performed. In brief, S. maurus palmatus crude venom $(30 \mu \mathrm{g} / \mathrm{ml})$ was added to the virus and/or cells at different time points relative to virus inoculation, as described in the Methods section: (i) pre-treatment of cells for $2 \mathrm{hr}(-2 \mathrm{hr}$ cells). This experiment examines whether there is any interaction between the venom and the cells. (ii) pre-treatment of virus for $2 \mathrm{hr}(-2 \mathrm{hr}$ virus). This experiment examines the possible virocidal activity of the venom. (iii) co-treatment of cells and virus during virus inoculation for $2 \mathrm{hr}(0 \mathrm{hr})$. This experiment examines the antiviral effect at the entry step. (iv) treatment of virus-infected cells during post-inoculation for $46 \mathrm{hr}$ $(+2 \mathrm{hr})$. This experiment examines the antiviral effect during the post-entry step. (v) co-treatment and postinoculation $(0 \mathrm{hr} \&+2 \mathrm{hr})$ as a positive control. For each set of experiments, HCV infectivity in culture supernatants was determined and compared with each other.

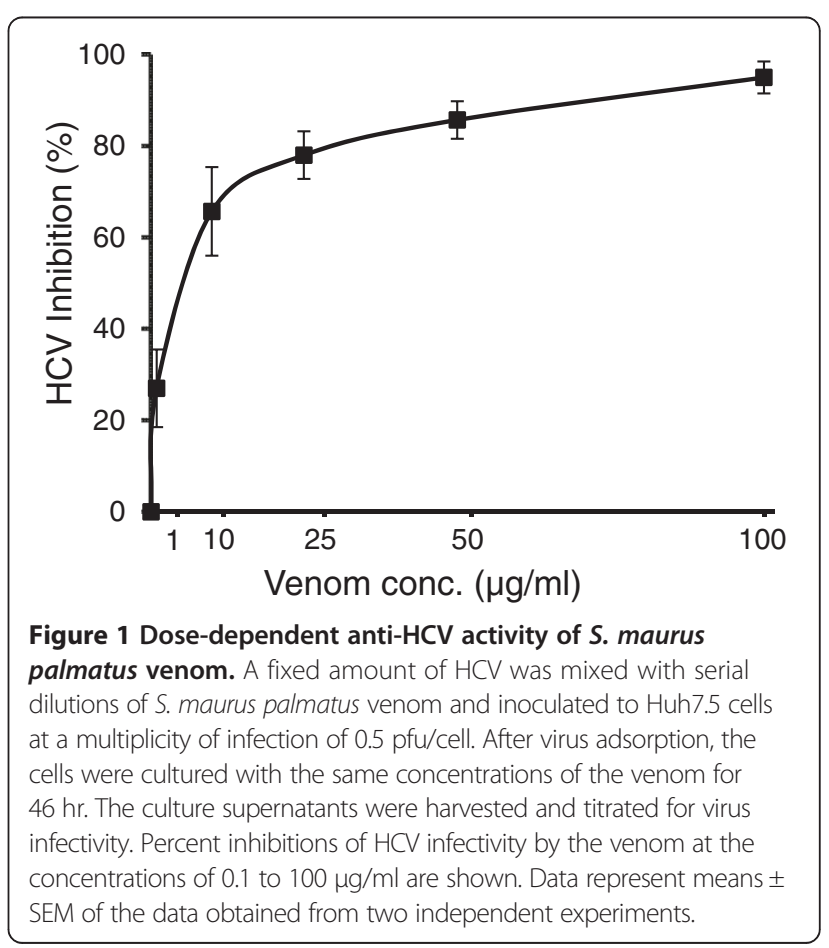


The result revealed that pre-treatment of virus for $2 \mathrm{hr}$ $(-2 \mathrm{hr}$ virus) markedly suppressed production of $\mathrm{HCV}$ infectious particles in culture supernatants while pretreatment of cells for $2 \mathrm{hr}(-2 \mathrm{hr}$ cells) only marginally suppressed it (Figure 2A). This suggested the possibility that $S$. maurus palmatus venom had direct virocidal activity. Also, treatment during post-inoculation for $46 \mathrm{hr}(+2 \mathrm{hr})$ suppressed HCV infectivity in culture supernatants, though to a lesser extent compared to pre-treatment of virus for $2 \mathrm{hr}$ ( $-2 \mathrm{hr}$ virus). The result suggested that this treatment inhibited either HCV replication in the cell or HCV infectivity outside the cells (in culture supernatants). On the other hand, treatment during post-inoculation for $46 \mathrm{hr}$ $(+2 \mathrm{hr})$ did not significantly inhibit HCV NS3 protein accumulation while pre-treatment of virus for $2 \mathrm{hr}(-2 \mathrm{hr}$ virus) completely inhibited it at 1 and 2 days post-infection (Figure 2B). We further examined HCV RNA replication and virus infectivity inside the cells. The result revealed that the post-inoculation treatment $(+2 \mathrm{hr})$ did not significantly inhibit HCV RNA replication in the cells (Figure 2C). Moreover, the venom treatment $(+2 \mathrm{hr})$ did not reduce $\mathrm{HCV}$ infectivity inside the cells (Figure 2D). Taken together, these results suggest that the $S$. maurus palmatus venom acts directly on $\mathrm{HCV}$ particles in culture medium to impair the viral infectivity and that it does not exert its antiviral effect inside the cells.

\section{Effects of neutralization of the proteinase activity by heating and/or a metalloproteinase inhibitor}

In order to investigate whether anti-HCV activity of $S$. maurus palmatus venom involves an enzymatic activity, we treated the venom $(30 \mu \mathrm{g} / \mathrm{ml})$ with heating at $60^{\circ} \mathrm{C}$ for $20 \mathrm{~min}$ or a metalloproteinase inhibitor, 1, 10-phenanthroline $(5 \mathrm{mM})$ to inactivate them, as reported by other

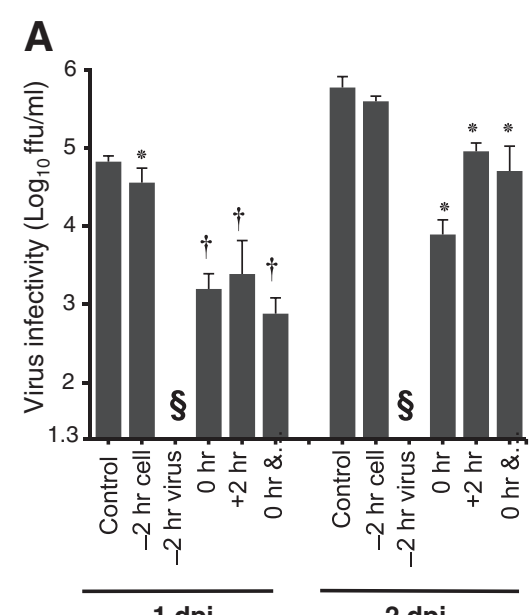

$1 \mathrm{dpi}$

$2 \mathrm{dpi}$

C

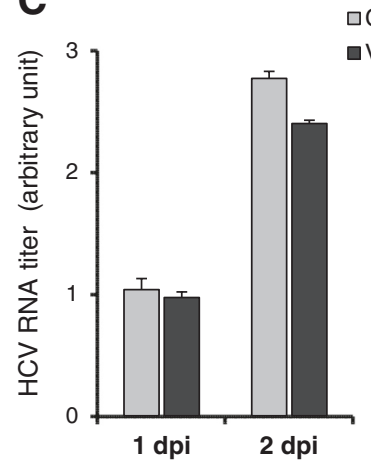

B

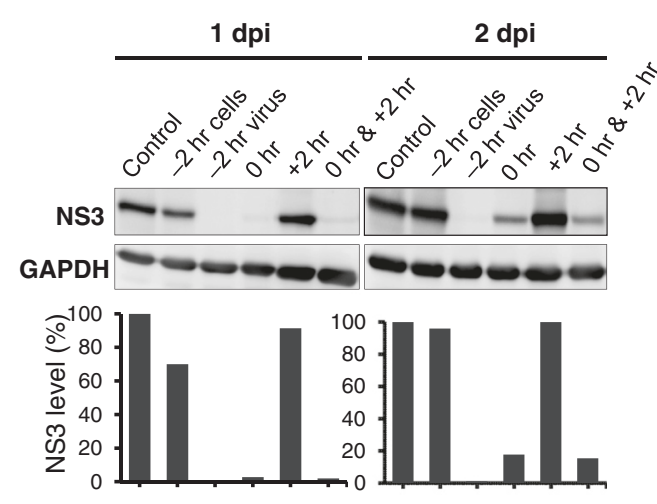

D

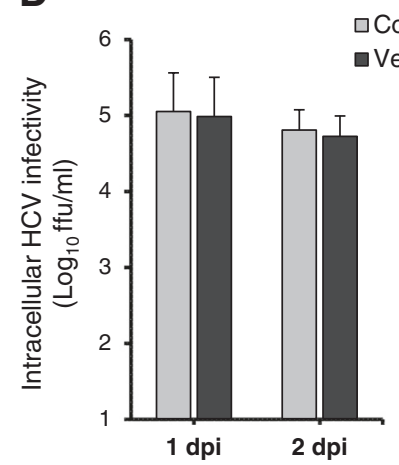

Figure 2 Analysis of mode-of-action of S. maurus palmatus venom. Huh7.5 cells were infected with HCV and treated with S. maurus palmatus venom $(30 \mathrm{\mu g} / \mathrm{ml})$ at different time points as indicated $(\mathbf{A}, \mathbf{B})$ or left untreated as a control. (A) Amounts of HCV infectious particles in the supernatants. Data represent means \pm SEM of the data obtained from two independent experiments. ${ }^{*}, P<0.05 ;+, P<0.001$, compared with the untreated control; $\S$, below the detection limit; dpi, days post-infection. (B) HCV NS3 protein accumulation in the cells. Virus-infected cells were subjected to immunoblot analysis using monoclonal antibody against the HCV NS3 protein at 1 and 2 days post-infection. GAPDH served as an internal control to verify equal amounts of sample loading. Signal intensities of NS3 were normalized to the corresponding GAPDH signal. (C) Amounts of HCV RNA in the cells. The venom treatment was done only during the post-inoculation (+2 hr) step. HCV RNA amounts were normalized to GAPDH mRNA expression. (D) Amounts of HCV infectious particles inside the cells. The venom treatment was done only during the post-inoculation (+2 hr) step. Virus-infected cells were subjected to 3 cycles of freezing and thawing at $-80^{\circ} \mathrm{C}$ and $37^{\circ} \mathrm{C}$, respectively, and $\mathrm{HCV}$ infectivity inside the cells was measured. 
investigators [31-34]. The treated venom was added to $\mathrm{HCV}$ and incubated for $2 \mathrm{hr}$ at $37^{\circ} \mathrm{C}$. Then, the virus/ venom mixture was inoculated to Huh7.5 cells and virus replication was analyzed. The results obtained revealed that the treated venom, either treated with heating at $60^{\circ} \mathrm{C}$ or the metalloproteinase inhibitor, or both at the same time, still markedly suppressed production of HCV infectious particles in the culture to the same extent compared to the untreated control (Figure 3A). Consistent with this observation, accumulation of intracellular HCV NS3 protein was also inhibited (Figure 3B).

\section{Specificity of antiviral activity of S. maurus palmatus venom}

In order to determine whether or not the antiviral activity of $S$. maurus palmatus venom shown above was specific to $\mathrm{HCV}$, we examined its possible effects on different viruses, such as dengue virus type 2 [35,36], measles virus [37] and influenza virus [38]. In this analysis, each virus was pre-treated with the venom (30 and $60 \mu \mathrm{g} / \mathrm{ml}$ ) for $2 \mathrm{hr}$ and the remaining virus infectivity was measured by infectious center or plaque assay. The result revealed that the venom exerted only weak inhibition on measles virus but strong inhibition on dengue virus (Figure 4A). Interestingly, the same venom did not inhibit but rather enhanced infectivity of influenza virus (Figure 4B).

\section{Discussion}

Venomous animals including scorpions have evolved a wide variety of peptide toxins for the purpose of predation and defense [39]. Scorpion venoms are a rich source of natural peptides and have been recognized as potential bioactive peptides $[24,39,40]$. cDNA library sequencing and proteomics profiling analyses have revealed that a single scorpion venom contains more than 100 peptidic components ranging in size from 1 to $9 \mathrm{kDa}[41,42]$. An increasing number of studies have shown that scorpion venoms and toxins possess antiviral activities in vitro and in vivo and are considered as a rich source for developing effective antiviral drugs [24,26-28,43,44].

In the present study, we screened crude venoms obtained from five Egyptian scorpion species for their possible anti-HCV activities. We observed that crude venoms of $S$. maurus palmatus and $A$. australis possessed anti$\mathrm{HCV}$ activities, with their $\mathrm{IC}_{50}$ values being $6.3 \pm 1.6$ and $88.3 \pm 5.8 \mu \mathrm{g} / \mathrm{ml}$, respectively (Table 1 ). We also demonstrated that $S$. maurus palmatus venom acts directly on $\mathrm{HCV}$ particles in culture supernatants to inhibit the viral infectivity (Figure 2A), suggesting the inhibition at the entry step, the first step of HCV life cycle. On the other hand, it was unlikely that the venom exerted its antiviral activity inside the cells (Figure 2B-D).

Scorpion venoms contain a wide variety of pharmacologically active peptides and proteins. Some of them possess enzymatic activities, such as metalloproteases, while others are non-enzymatic constituents $[18,45,46]$. It has been reported that the proteolytic activities of those enzymes were almost completely abolished by treatment with a matrix metalloproteinase inhibitor, 1, 10-phenanthroline $[31,32,47]$. Also, those enzymatic activities are known to be inactivated by heating at $60^{\circ} \mathrm{C}$ for $20 \mathrm{~min}[33,34,48]$. We

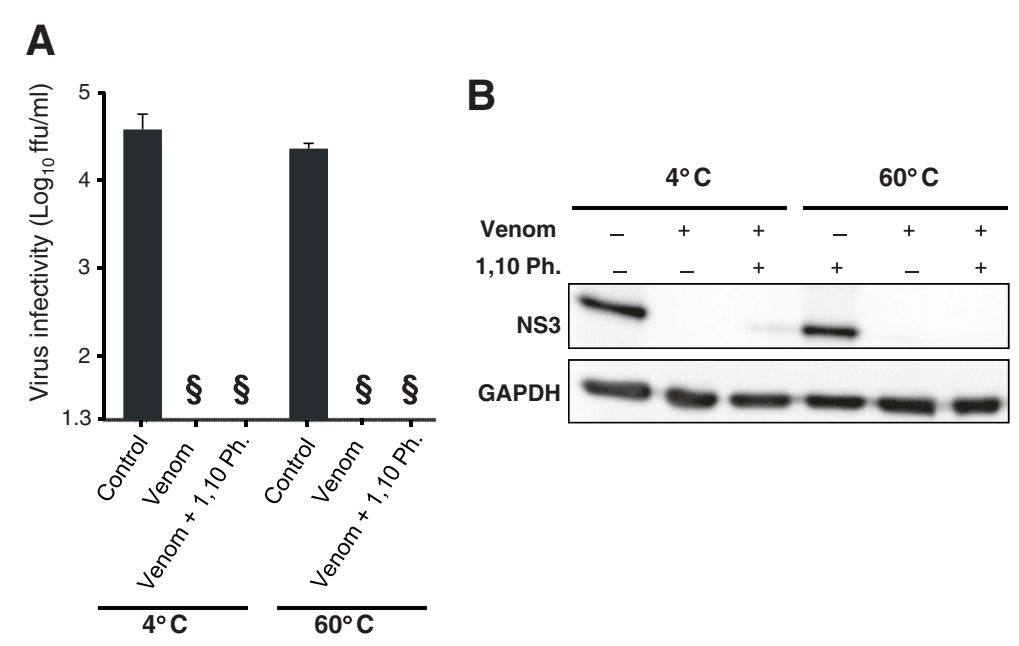

Figure 3 Effects of neutralization of the proteinase activities of the virocidal effects of S. maurus palmatus venom against HCV. S. maurus palmatus venom $(30 \mathrm{\mu g} / \mathrm{ml})$ was treated with a metalloproteinase inhibitor $(1,10$-phenan-throline; $5 \mathrm{mM})$ at $4^{\circ} \mathrm{C}$ or $60^{\circ} \mathrm{C}$ for $20 \mathrm{~min}$. The treated venom was mixed with $\mathrm{HCV}$ for $2 \mathrm{hr}$ at $37^{\circ} \mathrm{C}$ and the mixture was inoculated to Huh7.5 cells for $2 \mathrm{hr}$ at $37^{\circ} \mathrm{C}$. The cells were cultivated in the absence of the venom for one day. The culture supernatants were titrated for virus infectivity (A) and the cells were subjected to immunoblot analysis using monoclonal antibody against the HCV NS3 protein (B). GAPDH served as an internal control to verify equal amounts of sample loading. Data represent means \pm SEM of the data obtained from two independent experiments. 1,10 Ph., 1,10-phenanthroline; §, below the detection limit. 

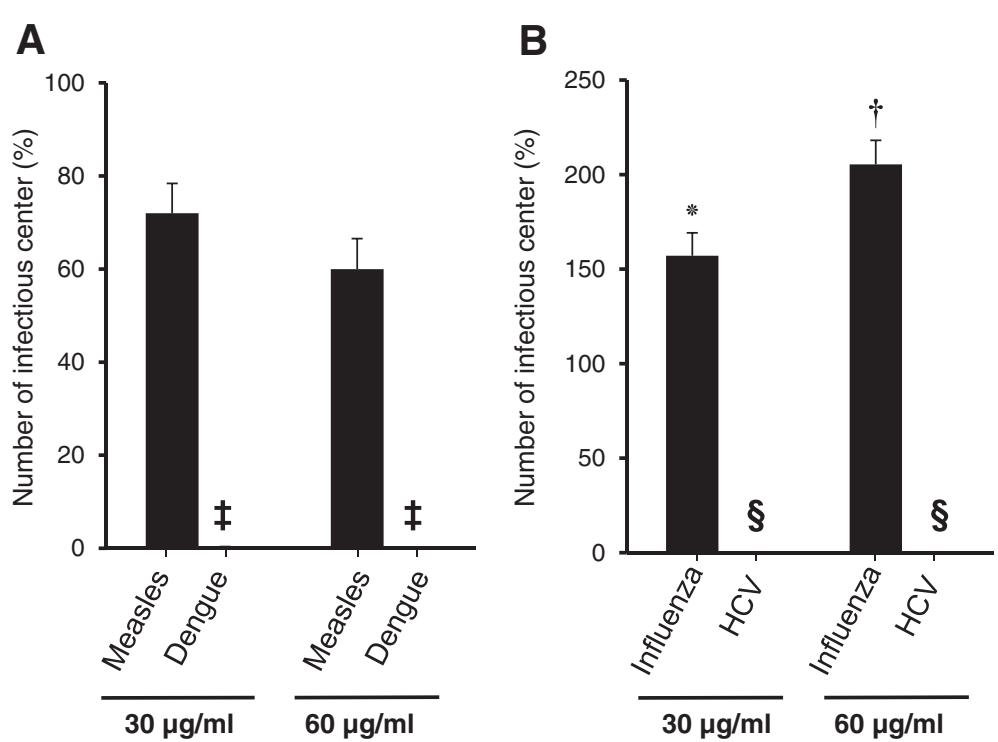

Figure 4 Antiviral activity of S. maurus palmatus venom against dengue virus, measles virus and influenza virus. (A) Dengue virus and measles virus that had been treated with S. maurus palmatus venom (30 and $60 \mu \mathrm{g} / \mathrm{ml}$ ) for $2 \mathrm{hr}$ or left untreated as a control were inoculated to Vero/SLAM cells and cultivated for $24 \mathrm{hr}$. The number of virus-infected cells was determined by immunofluorescence and plaque assays and the percentages compared to the untreated control calculated. Data represent means \pm SD of the data obtained from triplicate cultures. $\neq, \sim 0.2 \%$ of the control. (B) Influenza virus and HCV that had been treated with S. maurus palmatus venom (30 and $60 \mathrm{\mu g} / \mathrm{ml})$ for $2 \mathrm{hr}$ or left untreated were inoculated to MDCK and Huh7.5 cells, respectively. The number of virus-infected cells was determined by immunofluorescence analysis and the percentages of the numbers of virus-infected cells compared to the untreated control calculated. Data represent means \pm SEM of the data obtained from two independent experiments. ${ }^{*}, \mathrm{P}<0.05$;, , P $<0.001$, compared with the untreated control. $\S,<0.01 \%$ of the control.

made use of this information in our study and observed that treatment of the $S$. maurus palmatus venom with 1 , 10-phenanthroline and/or heating at $60^{\circ} \mathrm{C}$ for $20 \mathrm{~min}$ did not impair its anti-HCV activity (Figure 3 ). These results suggest that the anti-HCV activity of the S. maurus palmatus venom is independent of its proteinase activities.

Concerning the molecular mechanism(s) of the anti$\mathrm{HCV}$ activity, there was a possibility that venom peptides induced disruption in virus envelope (composed of lipid bilayer) through making pores in it. If this was the case, the venom might inhibit other envelope viruses than $\mathrm{HCV}$. To test this possibility, we used three different viruses, such as dengue virus type $2[35,36]$, another member of the family Flaviviridae, and measles virus [37] and influenza virus [38] that belong to the family Paramyxoviridae and Orthomyxoviridae, respectively. The results obtained demonstrated that $S$. maurus palmatus venom exerted strong inhibition on dengue virus and only weak inhibition on measles virus (Figure 4A). On the other hand, the same venom did not inhibit but rather enhanced influenza virus infectivity (Figure 4B). These results exclude the possibility that $S$. maurus palmatus venom inhibits all the envelope viruses, suggesting that the venom preferentially inhibits $\mathrm{HCV}$ and dengue virus, both of which belong to the family Flaviviridae, but not other viruses, e.g., influenza virus.
S. maurus palmatus venom has been reported to contain about 65 compounds, whose molecular masses vary from 413 to $14,009 \mathrm{Da}$, with a majority ranging between 3 and $5 \mathrm{kDa}$. A variety of putative bioactive molecules have been identified, such as neurotoxins (NaScTxs and KScTxs), calcines, La1-like peptides, insecticidal toxins and other AMPs [40]. Some of the scorpion venom peptides showed antiviral activities against certain viruses, such as measles virus, SARS coronavirus, H5N1 influenza virus [27], hepatitis B virus [49], herpes simplex virus 1 [28] and human immunodeficiency virus [50]. As for anti-HCV peptides from scorpion venoms, Yan et al. [26] reported that Hp1090 screened from the venomous gland cDNA library of the scorpion Heterometrus petersii inhibited HCV infection by targeting the viral membrane, disrupting its structural integrity. Also, Hong et al. [43] identified another anti-HCV peptide Ctry2459 from the venom peptide library of the scorpion Chaerilus tryznai. These peptides exerted a virocidal effect on $\mathrm{HCV}$ and some other viruses. Consistent with those results, we observed that S. maurus palmatus venom inhibited infectivity of $\mathrm{HCV}$ particles, suggesting direct virocidal activity of the venom. Interestingly, the antiviral activity of $S$. maurus palmatus venom is likely to be preferentially directed to $\mathrm{HCV}$ and dengue virus, both of which are members of the family Flaviviridae. Further 
studies using bioactivity-guided fractionation and purification analyses are needed to identify an active compound(s) responsible for this antiviral activity.

\section{Conclusions}

We screened crude venoms obtained from five Egyptian scorpion species for anti-HCV activities and demonstrated that $S$. maurus palmatus venom inhibits $\mathrm{HCV}$ infectivity through direct virocidal activity. In addition, this antiviral activity appeared to be independent of proteinase activities of the venom and is directed preferentially against $\mathrm{HCV}$, but not equally against all the enveloped viruses. To our knowledge, this is the first report describing antiviral activities of Egyptian scorpion venoms against $\mathrm{HCV}$, and has opened a new approach towards discovering antiviral compounds derived from scorpion venoms.

\section{Methods}

\section{Scorpions and venom preparation}

Adult scorpions were collected from different places in Egypt. They were fed with cockroaches and received water. The venoms were obtained from scorpions using electrical stimulation (12 to $20 \mathrm{~V}$ ) or by surgically separating venom glands from smaller scorpions, with the milked venoms being squeezed out into an Eppendorf tube using fine forceps, and solubilized in distilled water. The crude venoms thus obtained were centrifuged at $14,000 \mathrm{rpm}$ for $10 \mathrm{~min}$ at $4^{\circ} \mathrm{C}$. The supernatants were pooled, freeze-dried and stored at $-20^{\circ} \mathrm{C}$. The lyophilized samples were dissolved in distilled water, centrifuged at $15,000 \mathrm{rpm}$ for $15 \mathrm{~min}$ at $4{ }^{\circ} \mathrm{C}$ and the supernatants were stored at $-20^{\circ} \mathrm{C}$ until being used. Protein concentrations of the samples were determined using BCA Protein Assay Kit (Pierice Biotechnology, USA).

\section{Cell culture and viruses}

Huh7.5 cells and the plasmid pFL-J6/JFH1 to produce the J6/JFH1 strain of HCV genotype 2a [51] were kindly provided by Dr. C. M. Rice, The Rockefeller University, New York, NY, USA. Huh7.5 cells were cultivated in Dulbecco's modified Eagle's medium (Wako, Osaka, Japan) supplemented with fetal bovine serum (Biowest, Nuaille, France), non-essential amino acids (Invitrogen, Carlsbad, CA, USA), penicillin $(100 \mathrm{IU} / \mathrm{ml})$ and streptomycin $(100 \mu \mathrm{g} / \mathrm{ml})$ (Invitrogen). Cells were grown at $37^{\circ} \mathrm{C}$ in a $5 \% \mathrm{CO}_{2}$ incubator. The J6/JFH1-P47 strain [51] of HCV genotype 2a propagated in Huh7.5 cells was used in this study.

Dengue virus type 2 (Trinidad 1751 strain) [35,36], propagated in BHK-21 cells, was inoculated to Vero/ SLAM cells [52]. After virus adsorption for $1 \mathrm{hr}$, the virus-infected cells were cultivated in DMEM supplemented with $10 \%$ fetal bovine serum at $37^{\circ} \mathrm{C}$ in $5 \% \mathrm{CO}_{2}$.
Measles virus (K52 strain) [37], propagated in B95a cells, was inoculated to Vero/SLAM cells. After virus adsorption for $1 \mathrm{hr}$, the virus-infected cells were cultivated as described above.

Influenza A virus A/Udorn/307/72 (H3N2) was inoculated to Madin-Darby canine kidney (MDCK) cells for $60 \mathrm{~min}$ on ice and the virus-infected cells were cultivated in minimum essential medium (MEM; Life Technologies, Tokyo, Japan) containing $2.5 \mu \mathrm{g} / \mathrm{ml}$ TPCK-trypsin (Worthington Biochemical Corp., Lakewood, NJ, USA) and 100 units $/ \mathrm{ml}$ each of penicillin and streptomycin (GIBCO, Gland Island, NY, USA) at $37^{\circ} \mathrm{C}$ in $5 \% \mathrm{CO}_{2}$.

\section{Analysis of antiviral activities of crude venoms}

Huh7.5 cells were seeded in 24-well plates $\left(1.6 \times 10^{5}\right.$ cells/well). A fixed amount of HCV was mixed with serial dilutions of crude venoms $(0.1$ to $100 \mu \mathrm{g} / \mathrm{ml})$ and inoculated to the cells. After $2 \mathrm{hr}$, the cells were washed with medium to remove the residual virus and further incubated in medium containing the same concentrations of the crude venoms as those used during virus inoculation. Culture supernatants were obtained at 1 and 2 days post-infection (dpi) and titrated for virus infectivity. Virus and cells treated with medium served as controls. Percent inhibition of virus infectivity by the samples was calculated by comparing with the controls and 50\% inhibitory concentrations $\left(\mathrm{IC}_{50}\right)$ were determined.

\section{Virus titration}

$\mathrm{HCV}$ infectivity was determined as described previously [53]. In brief, virus samples were diluted serially 10-fold in complete medium and inoculated onto Huh7.5 cells seeded on glass coverslips in a 24-well plate. After virus adsorption for $2 \mathrm{hr}$, the cells were washed with medium to remove residual virus and cultured for $24 \mathrm{hr}$. The virusinfected cells were washed with phosphate-buffered saline (PBS), fixed with $4 \%$ paraformaldehyde for $20 \mathrm{~min}$ and permeabilized with $0.1 \%$ Triton X-100 in PBS for 15 min at room temperature. After being washed three times with PBS, the cells were incubated with HCV-infected patient's serum for $1 \mathrm{hr}$, followed by incubation with FITCconjugated goat anti-human IgG (Medical \& Biological Laboratories Co., Ltd., Nagoya, Japan). The cells were counterstained with Hoechst 33342 (Molecular Probes, Eugene, OR, USA) for $5 \mathrm{~min}$ and HCV-infected cells were counted under a BZ-9000 fluorescence microscope (Keyence, Osaka, Japan).

To determine intracellular HCV infectivity, freeze-andthaw experiments were performed. In brief, virus-infected cells were washed with PBS, harvested by trypsin treatment and centrifuged at $1,250 \mathrm{rpm}$ for $5 \mathrm{~min}$ at $20^{\circ} \mathrm{C}$. The cell pellets obtained were resuspended in $400 \mu \mathrm{l}$ of fresh medium and subjected to 3 cycles of freezing and thawing 
in a thermo block at $-80^{\circ} \mathrm{C}$ and $37^{\circ} \mathrm{C}$, respectively. The samples were centrifuged at $3,000 \mathrm{rpm}$ for $10 \mathrm{~min}$ at $4^{\circ} \mathrm{C}$ to remove cell debris, and $\mathrm{HCV}$ infectivity was measured by immunofluorescence staining, as described above.

To determine dengue virus infectivity, serially diluted virus was inoculated to Vero/SLAM cells and cultivated for $24 \mathrm{hr}$. The cells were subjected to indirect immunofluorescence analysis using mouse monoclonal antibody against dengue virus followed by Alexa Fluor A488 goat anti-mouse IgG (Life Technologies), as described above, and the number of infected cells counted.

Measles virus was inoculated to Vero/SLAM cells and cultivated for $24 \mathrm{hr}$. Plaques (virus-induced syncytia) forming on the monolayer cells were counted.

Influenza virus was inoculated to MDCK cells and cultivated for $6 \sim 8 \mathrm{hr}$. The cells were fixed with $4 \%$ paraformaldehyde for $10 \mathrm{~min}$ followed by cold methanol $\left(-30^{\circ} \mathrm{C}\right)$ for $5 \mathrm{~min}$ at room temperature. The fixed cells were incubated for 30 min with rabbit polyclonal antibody raised against purified influenza virus (A/Udorn/307/72 strain) [38]. After two washes, the cells were incubated for 30 min with Alexa Fluor A488 goat anti-rabbit IgG (Life Technologies) and Hoechst 33342 (to counterstain nuclei of all cells). The coverslips were mounted on a slide glass with Vectashield H-1000 reagent (Vector Laboratories, Inc. Burligame, CA) and observed using a fluorescence microscope.

\section{Time-of-addition experiments}

The crude venom was added at a final concentration of $30 \mu \mathrm{g} / \mathrm{ml}$ to the virus or cells at different time points relative to virus inoculation. Five sets of experiments were performed in parallel: (i) Pre-treatment of cells $(-2 \mathrm{hr}$ cells): venom was added to the cells for $2 \mathrm{hr}$ at $37^{\circ} \mathrm{C}$ followed by washing two times with medium before virus infection and incubated with medium without venom for $46 \mathrm{hr}$. (ii) Pre-treatment of virus ( $-2 \mathrm{hr}$ virus): the virus was mixed with the venom for $2 \mathrm{hr}$ at $37^{\circ} \mathrm{C}$, and then the mixture was inoculated to the cells for $2 \mathrm{hr}$ at $37^{\circ} \mathrm{C}$. After the virus/venom mixture was removed by washing two times, the cells were incubated with medium without venom for $46 \mathrm{hr}$. (iii) Co-treatment of cells and virus during virus inoculation $(0 \mathrm{hr})$ : Virus/ venom mixture was inoculated to the cells and incubated for $2 \mathrm{hr}$. After the virus/venom mixture was removed by washing two times, the cells were incubated with medium without venom for $46 \mathrm{hr}$. (iv) Treatment during post-inoculation $(+2 \mathrm{hr})$ : Cells were infected with the virus for $2 \mathrm{hr}$ in the absence of the venom. After the virus was removed by washing two times, the cells were incubated with medium containing the venom for $46 \mathrm{hr}$. (v) Co-treatment during inoculation and post-inoculation $(0 \mathrm{hr} \&+2 \mathrm{hr})$ : As a positive control, virus/venom mixture was inoculated to the cells and incubated for $2 \mathrm{hr}$. After the virus/venom mixture was removed by washing two times, the cells were incubated with medium containing the venom for $46 \mathrm{hr}$. In each set of experiments, the supernatants were collected and titrated for virus infectivity. Also, the cells were subjected to immunoblot analysis for intracellular accumulation of viral and host proteins.

\section{WST-1 assay for cytotoxicity test}

WST-1 assay was performed as described previously with a slight modification [53]. In brief, Huh7.5 cells plated in 96-well plates were treated with serial dilutions of crude venoms or complete medium as a control for $48 \mathrm{hr}$ at $37^{\circ} \mathrm{C}$. After this treatment, $10 \mu \mathrm{l}$ of WST- 1 reagent (Roche, Mannheim, Germany) was added to each well and the cells were cultured for $4 \mathrm{hr}$. The WST-1 reagent is absorbed by the cells and converted to formazan by mitochondrial dehydrogenases. The amount of formazan, which correlates with the number of living cells, was determined by measuring the absorbance of each well using a microplate reader at 450 and $630 \mathrm{~nm}$. Percent cell viability compared to the control was calculated for each dilution of the venoms and $50 \%$ cytotoxic concentrations $\left(\mathrm{CC}_{50}\right)$ were determined.

\section{Immunoblot analysis}

Cells were lysed with SDS sample buffer and equal amounts of protein were subjected to SDS-polyacrylamide gel electrophoresis. The separated proteins were transferred onto a polyvinylidene difluoride membrane (Millipore, Bedford, MA, USA). The membrane was blocked by incubation with 5\% skim milk and incubated with the respective primary antibodies. The primary antibodies used were mouse monoclonal antibodies against HCV NS3 and GAPDH (Millipore). Horseradish peroxidase-conjugated goat anti-mouse immunoglobulin (Invitrogen) was used to visualize the respective proteins by means of an enhanced chemiluminescence detection system (ECL; GE Healthcare, Buckinghamshire, UK).

\section{Real-time quantitative RT-PCR}

Total RNA was extracted from the cells using a ReliaPrep RNA cell miniprep system (Promega, Madison, WI, USA) according to the manufacturer's instructions. One $\mu \mathrm{g}$ of total RNA was reverse transcribed using a GoScript Reverse Transcription system (Promega) with random primers and subjected to quantitative real-time PCR analysis using SYBR Premix Ex Taq (TaKaRa, Kyoto, Japan) in a MicroAmp 96-well reaction plate and an ABI PRISM 7500 system (Applied Biosystems, Foster City, CA, USA). The primers used to amplify an NS5A region of the HCV genome were 5 '-AGACGTATTGAGGT CCATGC-3' (sense) and 5' CCGCAGCGACGGTGCT GATAG-3' (antisense). As an internal control, human glyceraldehyde-3-phosphate dehydrogenase (GAPDH) 
gene expression levels were measured using primers 5' GCCATCAATGACCCCTTCATT-3' (sense) and 5' TCTCGCTCCTGGAAGATGG-3'.

\section{Neutralization of the proteinase activities of scorpion crude venom by heating and a metalloproteinase inhibitor}

Crude venom $(30 \mu \mathrm{g} / \mathrm{ml})$ was heated at $60^{\circ} \mathrm{C}$ for $20 \mathrm{~min}$ or treated with a metalloprotease inhibitor (1,10-phenanthroline; $5 \mathrm{mM}$ ) [31-34] at $4{ }^{\circ} \mathrm{C}$ or $60^{\circ} \mathrm{C}$ for $20 \mathrm{~min}$. The treated venom or untreated control was mixed with $\mathrm{HCV}$ for $2 \mathrm{hr}$ at $37^{\circ} \mathrm{C}$. The virus/venom mixture was then inoculated to Huh7.5 cells for $2 \mathrm{hr}$ at $37^{\circ} \mathrm{C}$. After the virus inoculation, the cells were washed three times and incubated with medium without venom. After $48 \mathrm{hr}$, culture supernatants were collected and virus infectivity was titrated. The virus-infected cells were subjected to immunoblot analysis to check the level of HCV protein accumulation, as described above.

\section{Statistical analysis}

Data are representative of at least 2 independently repeated experiments and presented as mean \pm SEM. The statistical significance was examined using Student's ttest. $P$ value of $<0.05$ was considered significant.

\section{Abbreviations}

HCV: Hepatitis C virus; SVR: Sustained virological response; AMPs: Antimicrobial peptides; $C_{50}$ : 50\% cytotoxic concentration; $I_{50}$ : 50\% inhibitory concentration; SI: Selectivity index; 1, 10 Ph: 1,10-phenanthroline.

\section{Competing interests}

The authors declare that they have no competing interests.

\section{Authors' contributions}

AMHE, MMHS, MAM and HH conceived, designed, supervised and coordinated the study. AMHE and MMHS collected scorpions and prepared their crude venom. AMHE carried out all the main experiments, analyzed results and drafted the manuscript. CA, LD and YT conducted part of anti-HCV and antiinfluenza virus bioassays, respectively. MK conducted part of anti-dengue virus and anti-measles virus bioassays. MMHS, CA and YT wrote part of the manuscript. All the authors read and approved the final manuscript.

\section{Acknowledgements}

The authors are grateful to Dr. C. M. Rice (The Rockefeller University, New York, NY, USA) for providing Huh7.5 cells and pFL-J6/JFH1. Thanks are also due to Mr. Hamdy A.M. Aly (Al Azhar University, Assiut, Egypt) for his assistance in scorpion collection. This study was conducted under collaboration between Department of Zoology, Al Azhar University, Faculty of Science, Assiut, Egypt and Division of Microbiology, Kobe University Graduate School of Medicine, Japan, and was supported in part by a scholarship from the Egyptian Ministry of Higher Education, Cultural Affairs and Missions sector according to a joint supervision program between Egypt and Japan. This work was also performed as part of the Science and Technology Research Partnership for Sustainable Development (SATREPS) program supported by Japan Science and Technology Agency (JST) and Japan International Cooperation Agency (JICA) and also supported in part through the programs of the Japan Initiative for Global Research Network on Infectious Diseases (J-GRID) by the Ministry of Education, Culture, Sports, Science and Technology, Japan.

\section{Author details}

'Department of Zoology, Faculty of Science, Al-Azhar University, Assiut, Egypt. ${ }^{2}$ Division of Microbiology, Kobe University Graduate School of Medicine, 7-5-1 Kusunoki-cho, Chuo-ku, Kobe 650-0017, Hyogo, Japan.

Received: 30 November 2014 Accepted: 9 March 2015

Published online: 24 March 2015

\section{References}

1. Moradpour D, Penin F, Rice CM. Replication of hepatitis C virus. Nat Rev Micro. 2007:5:453-63.

2. Lindenbach $B D$, Rice $C M$. Unravelling hepatitis $C$ virus replication from genome to function. Nature. 2005;436:933-8.

3. Calland N, Dubuisson J, Rouillé Y, Séron K. Hepatitis C virus and natural compounds: a new antiviral approach? Viruses. 2012;4:2197-217.

4. Gentile I, Borgia F, Coppola N, Buonomo AR, Castaldo G, Borgia G. Daclatasvir: the first of a new class of drugs targeted against hepatitis $C$ virus NS5A. Curr Med Chem. 2014;21:1391-404.

5. Suzuki F, Toyota J, Ikeda K, Chayama K, Mochida S, Hayashi N, et al. A randomized trial of daclatasvir with peginterferon alfa- $2 \mathrm{~b}$ and ribavirin for HCV genotype 1 infection. Antivir Ther. 2014;19:491-9.

6. Poordad F, Lawitz E, Kowdley KV, Cohen DE, Podsadecki T, Siggelkow S, et al. Exploratory study of oral combination antiviral therapy for hepatitis $C$. N Engl J Med. 2013;368:45-53.

7. Lok AS, Gardiner DF, Hèzode C, Lawitz EJ, Bourlière M, Everson GT, et al. Randomized trial of daclatasvir and asunaprevir with or without PegIFN/RBV for hepatitis C virus genotype 1 null responders. J Hepatol. 2014;60:490-9.

8. Everson GT, Sims KD, Rodriguez-Torres M, Hezode C, Lawitz E, Bourliere M, et al. Efficacy of an interferon- and ribavirin-free regimen of daclatasvir, asunaprevir, and BMS-791325 in treatment-naive patients With HCV genotype 1 Infection. Gastroenterol Hepatol. 2013;146:420-9.

9. Li Z, Xu X, Meng L, Zhang Q, Cao L, Li W, et al. Hp1404, a new antimicrobial peptide from the scorpion heterometrus petersii. PLoS One. 2014;9:e97539.

10. Zhang X-X, Eden HS, Chen X. Peptides in cancer nanomedicine: drug carriers, targeting ligands and protease substrates. J Control Release. 2012;159:2-13.

11. Wang Z, Wang G. APD: the Antimicrobial peptide database. Nucleic Acids Res. 2004;32:590-2

12. Hv J, Hamill P, Hancock REW. Peptide antimicrobial agents. Clin Microbiol Rev. 2006;19:491-511.

13. Zasloff M. Antimicrobial peptides of multicellular organisms. Nature. 2002:415:389-95.

14. Ma Y, Zhao R, Li S, Fan S, Wu Y, Liu H, et al. Characterization of LmTxLP11 and LmVP1.1 transcripts and genomic organizations: alternative splicing contributing to the diversity of scorpion venom peptides. Toxicon. 2009:53:129-34.

15. Possani LD, Merino E, Corona M, Bolivar F, Becerril B. Peptides and genes coding for scorpion toxins that affect ion-channels. Biochimie. 2000;82:861-8.

16. Zhijian C, Feng L, Yingliang W, Xin M, Wenxin L. Genetic mechanisms of scorpion venom peptide diversification. Toxicon. 2006:47:348-55.

17. Possani LD, Rodrìguez de la Vega RC, Kastin AJ. Scorpion venom peptides. In: Handbook of biologically active peptides. Burlington: Academic Press; 2006. p. 339

18. Goudet C, Chi C-W, Tytgat J. An overview of toxins and genes from the venom of the Asian scorpion Buthus martensi Karsch. Toxicon. 2002; $40: 1239-58$

19. Zeng X-C, Corzo G, Hahin R. Scorpion venom peptides without disulfide bridges. IUBMB Life. 2005;57:13-21.

20. Abdel-Rahman MA, Omran MAA, Abdel-Nabi IM, Nassier OA, Schemerhorn BJ. Neurotoxic and cytotoxic effects of venom from different populations of the Egyptian Scorpio maurus palmatus. Toxicon. 2010;55:298-306.

21. Albiol Matanic VC, Castilla V. Antiviral activity of antimicrobial cationic peptides against Junin virus and herpes simplex virus. Int J Antimicrob Agents. 2014;23:382-9.

22. Sun L, Finnegan CM, Kish-Catalone T, Blumenthal R, Garzino-Demo P, La Terra Maggiore GM, et al. Human $\beta$-defensins suppress human immunodeficiency virus infection: potential role in mucosal protection. J Virol. 2005;79:14318-29.

23. Carriel-Gomes MC, Kratz JM, Barracco MA, Bachére E, Barardi CRM, Simões CMO. In vitro antiviral activity of antimicrobial peptides against herpes simplex virus 1, adenovirus, and rotavirus. Mem Inst Oswaldo Cruz. 2007;102:469-72 
24. Dai C, Ma Y, Zhao Z, Zhao R, Wang Q, Wu Y, et al. Mucroporin, the first cationic host defense peptide from the venom of Lychas mucronatus. Antimicrob Agents Chemother. 2008;52:3967-72.

25. Mohan KVK, Rao SS, Atreya CD. Antiviral activity of selected antimicrobial peptides against vaccinia virus. Antiviral Res. 2010;86:306-11.

26. Yan R, Zhao Z, He Y, Wu L, Cai D, Hong W, et al. A new natural a-helical peptide from the venom of the scorpion Heterometrus petersii kills HCV. Peptides. 2011:32:11-9.

27. Li Q, Zhao Z, Zhou D, Chen Y, Hong W, Cao L, et al. Virucidal activity of a scorpion venom peptide variant mucroporin-M1 against measles, SARS-CoV and influenza H5N1 viruses. Peptides. 2011;32:1518-25.

28. Hong W, Li T, Song Y, Zhang R, Zeng Z, Han S, et al. Inhibitory activity and mechanism of two scorpion venom peptides against herpes simplex virus type 1. Antiviral Res. 2014;102:1-10.

29. Harrison PL, Abdel-Rahman MA, Miller K, Strong PN. Antimicrobial peptides from scorpion venoms. Toxicon. 2014;88:115-37.

30. Abdel-Nabi IM, McVean A, Abdel-Rahman MA, Omran MAA. Intraspecific diversity of morphological characters of the burrowing scorpion Scorpio maurus palmatus (Ehrenberg, 1828) in Egypt (Arachnida: Scorpionida: Scorpionidae). Serket. 2004;9:41-67.

31. Seyedian R, Pipelzadeh MH, Jalali A, Kim E, Lee H, Kang C, et al. Enzymatic analysis of Hemiscorpius lepturus scorpion venom using zymography and venom-specific antivenin. Toxicon. 2010;56:521-5.

32. Venancio EJ, Portaro FCV, Kuniyoshi AK, Carvalho DC, Pidde-Queiroz G, Tambourgi DV. Enzymatic properties of venoms from Brazilian scorpions of Tityus genus and the neutralisation potential of therapeutical antivenoms. Toxicon. 2013;69:180-90.

33. Pessini AC, Takao TT, Cavalheiro EC, Vichnewski W, Sampaio SV, Giglio JR, et al. A hyaluronidase from Tityus serrulatus scorpion venom: isolation, characterization and inhibition by flavonoids. Toxicon. 2001;39:1495-504.

34. Sutti R, Tamascia M, Hyslop S, Rocha-e-Silva T. Purification and characterization of a hyaluronidase from venom of the spider Vitalius dubius (Araneae, Theraphosidae). J Venom Anim Toxins Incl Trop Dis. 2014;20:1-7.

35. Hotta H, Hotta S, Takada H, Kotani S, Tanaka S, Ohki M. Enhancement of dengue virus type 2 replication in mouse macrophage cultures by bacterial cell walls, peptidoglycans, and a polymer of peptidoglycan subunits. Infect Immun. 1983:41:462-9.

36. Hotta H, Homma M. Lectin-mediated enhancement of dengue virus infection in a mouse macrophage cell line Mk1. Arch Virol. 1994;134:51-9.

37. Otaki M, Sada K, Kadoya H, Nagano-Fujii M, Hotta H. Inhibition of measles virus and subacute sclerosing panencephalitis virus by RNA interference. Antiviral Res. 2006;70:105-11.

38. Shimizu K, Mukaigawa J, Oguro M, Ono Y, Nakajima K, Kida H. Inhibition of transcriptase activity of influenza $A$ virus in vitro by anti-haemagglutinin antibodies. Vaccine. 1985;3:207-10.

39. Lewis RJ, Garcia ML. Therapeutic potential of venom peptides. Nat Rev Drug Discov. 2003;2:790-802.

40. Abdel-Rahman MA, Quintero-Hernandez V, Possani LD. Venom proteomic and venomous glands transcriptomic analysis of the Egyptian scorpion Scorpio maurus palmatus (Arachnida: Scorpionidae). Toxicon. 2013;74:193-207.

41. Diego-Garcia E, Batista CVF, Garcia-Gomez Bl, Lucas S, Candido DM, GomezLagunas F, et al. The Brazilian scorpion Tityus costatus Karsch: genes, peptides and function. Toxicon. 2005;45:273-83.

42. Kennedy AD, Otto M, Braughton KR, Whitney AR, Chen L, Mathema B, et al. Epidemic community-associated methicillin-resistant Staphylococcus aureus: recent clonal expansion and diversification. Proc Natl Acad Sci U S A. 2008;105:1327-32.

43. Hong W, Zhang R, Di Z, He Y, Zhao Z, Hu J, et al. Design of histidine-rich peptides with enhanced bioavailability and inhibitory activity against hepatitis C virus. Biomaterials. 2013;34:3511-22.

44. Ortiz E, Gurrola GB, Schwartz EF, Possani LD. Scorpion venom components as potential candidates for drug development. Toxicon. 2015;93:125-35.

45. Feng L, Gao R, Gopalakrishnakone P. Isolation and characterization of a hyaluronidase from the venom of Chinese red scorpion Buthus martensi. Comp Biochem Physiol C Pharmacol Toxicol Endocrinol. 2008;148:250-7.

46. Kanoo S, Deshpande SB. Involvement of phospholipase A2 pathway for the Indian red scorpion venom-induced augmentation of cardiopulmonary reflexes elicited by phenyldiguanide. Neurosci Lett. 2008;440:242-5.

47. Beynon R, Bond JS. Proteolytic enzymes: a practical approach: Oxford University Pres. 2001.
48. Venkateswarlu Y, Janakiram B, Reddy GR. In vitro neutralization of the scorpion, Buthus tamulus venom toxicity. Indian J Physiol Pharmacol. 1988;32:187-94.

49. Zhao Z, Hong W, Zeng Z, Wu Y, Hu K, Tian X, et al. Mucroporin-M1 inhibits hepatitis $B$ virus replication by activating the mitogen-activated protein kinase (MAPK) pathway and down-regulating HNF $4 a$ in vitro and in vivo. J Biol Chem. 2012;287:30181-90.

50. Chen Y, Cao L, Zhong M, Zhang Y, Han C, Li Q, et al. Anti-HIV-1 activity of a new scorpion venom peptide derivative Kn2-7. PLoS One. 2012;7:34947.

51. Lindenbach BD, Evans MJ, Syder AJ, WÃlk B, Tellinghuisen TL, Liu CC, et al. Complete replication of hepatitis $C$ virus in cell culture. Science. 2005;309:623-6.

52. Ono N, Tatsuo H, Hidaka Y, Aoki T, Minagawa H, Yanagi Y. Measles viruses on throat swabs from measles patients use signaling lymphocytic activation molecule (CDw150) but not CD46 as a cellular receptor. J Virol. 2001;75:4399-401.

53. Deng L, Adachi T, Kitayama K, Bungyoku Y, Kitazawa S, Ishido S, et al. Hepatitis $C$ virus infection induces apoptosis through a Bax-triggered, mitochondrion-mediated, caspase 3-dependent pathway. J Virol. 2008;82:10375-85.

\section{Submit your next manuscript to BioMed Central and take full advantage of:}

- Convenient online submission

- Thorough peer review

- No space constraints or color figure charges

- Immediate publication on acceptance

- Inclusion in PubMed, CAS, Scopus and Google Scholar

- Research which is freely available for redistribution 